\title{
Retraction
}

\section{Retracted: The Roles of Angiogenesis in Malignant Melanoma: Trends in Basic Science Research over the Last 100 Years}

\author{
ISRN Oncology \\ Received 7 November 2012; Accepted 7 November 2012 \\ Copyright (C 2012 ISRN Oncology. This is an open access article distributed under the Creative Commons Attribution License, \\ which permits unrestricted use, distribution, and reproduction in any medium, provided the original work is properly cited.
}

This article has been retracted as it was submitted for publication without the knowledge and approval of the coauthors Maxine Emmett and Rowan Pritchard Jones [1].

\section{References}

[1] D. Dewing, M. Emmett, and R. Pritchard Jones, "The roles of angiogenesis in malignant melanoma: trends in basic science research over the last 100 years," ISRN Oncology, vol. 2012, Article ID 546927, 7 pages, 2012. 